\title{
Precarious Workers and Probationary Wives: How Immigration Law Discriminates Against Women
}

\author{
Catherine Briddick*
}

\section{Keywords}

migration status; immigration law; indirect discrimination; sex discrimination; stereotypes; wife; domestic worker; labour migration;

\begin{abstract}
Immigration law prescribes a range of statuses into one of which individuals must try to fit to be allowed entry. This range establishes a hierarchy from highly advantageous forms of permission to enter or remain in the UK to ones to which few rights accrue, which create dependency or are precarious. Against the backdrop of this hierarchy I make two claims: that women are disadvantaged by immigration law's distribution of migration statuses; and, that this disadvantage is the result of rules which indirectly discriminate against women, discrimination which may be unlawful under Article 14 ECHR. As it is well-established that indirect discrimination may be revealed by statistical information, I rely on data from over ten years to demonstrate that certain migration opportunities are distributed differently to women and men. This distribution is then subjected to scrutiny, potential 'justifications' for it, including those premised on sexed/gendered stereotypes, being analysed and refuted. Finally, an understanding of women's disadvantageous and discriminatory treatment in relation to the family and labour migration routes considered, is combined with a broader consideration of gendered patterns of migration and the statuses that such patterns produce, to found the normative claim that immigration law as whole disadvantages women.
\end{abstract}

\section{INTRODUCTON}

Immigration law prescribes a range of migration statuses into one of which individuals must try to fit to be allowed entry. This range establishes a hierarchy, from highly advantageous forms of permission to enter or remain in the UK at the top to ones to which

\footnotetext{
Martin James Departmental Lecturer in Gender and Forced Migration, Refugee Studies Centre, Oxford Department of International Development, University of Oxford, 3 Mansfield Road, Oxford OX1 3TB. Email catherine.briddick@qeh.ox.ac.uk
}

I would like to thank Prof Denise Réaume, Prof Carolyn Hoyle, Prof Tarun Khaitan and two anonymous reviewers for commenting on various drafts of this article. Particular thanks are due to Prof Cathryn Costello for all of her comments, guidance and support. 
few rights accrue, which create dependency or are precarious at the bottom. A person's migration status determines how long she or he is permitted by law to remain in the UK (a few months, years or permanently), on what basis (as a visitor, student, family member, worker or permanent resident) and what rights she or he has whilst here (to work, to study, to access welfare benefits or healthcare, to bring family members and/or to settle here permanently). A person's migration status is also determinative of an ever-increasing plethora of social rights, including the ability to open a bank account, rent private accommodation or hold a driving licence (see Part 2, Immigration Act 2016 and YuvalDavis et al., 2018). In the UK some migration statuses, such as 'indefinite leave to remain', bestow rights that are almost analogous to those enjoyed by British citizens/subjects, whilst others, such as 'temporary admission', provide only a very limited ability to enter and confer very few rights. Migration status is 'at once transient and indelible', determining rights for a particular fixed period, but often also having an enduring impact, even after the 'migrant' has become a 'citizen' (Freedland and Costello, 2014:4).

Against the backdrop of this hierarchy I make two claims about contemporary British immigration law and the migration statuses it creates. First, that women are disadvantaged by immigration law's distribution of migration statuses. Second, that this disadvantage is the result of rules and practices which may unlawfully discriminate on the grounds of sex.

Both indirect and direct discrimination on suspect grounds have and continue to be features of immigration law. Consider, for example, the provisions of the Commonwealth Immigrants Act 1962 (challenged in East African Asians v UK [1973]) which extended immigration control to the citizens of independent Commonwealth countries and those of 
British dependencies who had passports issued by the colonial, rather than UK government (indirect discrimination on the grounds of race) or the rule challenged in Abdulaziz, Cabales and Balkandali v UK [1985] that allowed resident husbands to bring their wives to the UK, but denied resident wives the equivalent right (direct discrimination on the grounds of sex). An appreciation of the prevalence and role of both indirect and direct discrimination in immigration law enables us to see through what Bridget Anderson describes as the "taken-for-grantedness of immigration controls which views them as neutral sorting mechanisms, and to consider them as a factor in shaping action and process productive of certain types of relations' (2013: 70). As Anderson and others (Anderson, 2013; Wray, 2006) have observed, immigration law distributes migration opportunities to certain groups of people to the exclusion and disadvantage of others. Whilst the gendered and racialised underpinnings of particular rules and decisions have been highlighted (de Hart, 2007; van Walsum, 2006) and individual sections or paragraphs of the immigration rules impugned on the grounds that they unlawfully discriminate on the grounds of sex and race (Wray and Kofman, 18 February 2016), I draw on a rich vein of scholarly engagement with immigration law (Dauvergne, 2009; Kofman, 2014b; Macklin, 2003) to argue that the distribution of certain family and labour migration statuses not only disadvantages women, but indirectly discriminates against them. In advancing this argument, this article contributes to migration law scholarship and feminist jurisprudence an improved understanding of migration status and the role of sex/gender and sexed/gendered stereotypes, not only in underpinning various (other) forms of disadvantage and exclusion (such as those premised on race, Wray, 24 April 2015), but as a source of disadvantage and exclusion in its own right. 
Before setting out my substantive arguments, it is necessary to introduce the methodology and terminology I employ. I reviewed publicly available Home Office statistical reports from 2004-2017 to ascertain the number and proportion of women and men who were granted various migration statuses, including those of husband, wife, skilled labour migrant and domestic worker. Where relevant statistical information was not disaggregated by sex (such as that pertaining to the number of labour migrants who hold particular migration statuses) I made a series of freedom of information requests to obtain it for particular years/migration statuses during the reviewed period. Having established that different migration statuses are distributed differently to women and men to women's disadvantage, I rely on Article 14 of the European Convention on Human Rights (ECHR) to demonstrate that the rules that determine this distribution may discriminate against women. Throughout the article I draw on language used in either the Home Office's statistical reports or particular immigration rules. ${ }^{1}$ In referring to 'wives' as 'she' or skilled labour migrants as 'he', I seek to highlight, not reproduce, the Home Office's and immigration law's categorisation(s) of migrant women and examine (just) one of the types of discrimination that produces these categorisation(s). As will become apparent, stereotypes based on sex/gender, sexual orientation and family relationships are 'written' into immigration law in a way that would be considered unacceptable in other legal domains. Finally, whilst many of the arguments advanced here could be applied to European Union (EU) free movement law (see for example O'Brien, 2016; Shutes and 
Walker, 2018) the focus of this article is British immigration law, specifically the immigration rules.

The article proceeds as follows: in section $1 \mathrm{I}$ introduce the discrimination law framework I rely on and anticipate and rebut two potential objections to my claim that women are disadvantaged and discriminated against by particular immigration rules. In section 2 I set out the rules that apply to certain family and labour migrants, discussing the migration statuses they produce and their position within the status-based hierarchy that immigration law creates. In section 3 I draw on statistical information to establish 'who' is 'where' in the main family and labour migration routes to reveal, in section 4, the sexed/gendered disadvantage that pertains to immigration law's distribution of migration statuses. To foreshadow the more detailed discussion engaged in in sections 2, 3 and 4: three quarters of those who are accorded the relatively advantageous migration status of 'skilled' labour migrant are men; whilst three quarters of those accorded the highly disadvantageous status of 'domestic worker' are women. Nearly three quarters of those accorded the relatively disadvantageous status of 'partner' are 'women-as-wives'. In section 5 I evaluate the rules that determine who may enter and remain in the UK as a partner or domestic worker, arguing that these rules may indirectly discriminate against women. In doing so I also contend that the migration status of 'partner', 'skilled labour migrant' and 'domestic worker' are premised on and reinforce stereotypical understand ings of men's and women's roles and attributes. In the final section I consider migration for 
work, family and protection more broadly, arguing that immigration law, as a whole, may disadvantage women.

\section{UNLAWFUL INDIRECT DISCRIMINATION ON THE GROUNDS OF SEX IN A LEGAL DOMAIN WHICH DIFFERENTIATES ON THE GROUNDS OF NATIONALITY}

Migrants in the UK are protected from unlawful discrimination by the Human Rights Act 1998 (the HRA) (which incorporated the ECHR into domestic law) and the Equality Act 2010. In line with both the relevant jurisprudence and literature, the discrimination law analysis engaged in here will centre on the ECHR's prohibition of indirect discrimination, with the specific obligations placed on public authorities by the Equality Act 2010 referred to where necessary. ${ }^{2}$

Article 14 ECHR, the right not to be discriminated against, is not a free-standing right to equal treatment. Consequently, any difference in treatment complained of must relate to the exercise of a protected right, such as the right to private and family life under Article 8. To rely on Article 14, an applicant or group does not have to show that one of the substantive rights within the ECHR or its protocols has been breached, only that the 'facts at issue fall within the ambit' of the protected 'rights and freedoms' (Weller $v$ Hungary [2009] para 26). Article 8 is engaged in immigration cases involving marriage and other significant family relationships and where a person's employment and social 
connections are affected by a particular policy or practice (Biao v Denmark [2016]; Emel Boyraz v Turkey [2014]).

Discrimination law claims are, in general, comparative and grounds-based. To successfully bring a claim an applicant or a group has to show that they have been treated differently in comparison with members of a comparator group. Different systems identify different 'grounds', or protected characteristics, as requiring of protection. Whilst the Equality Act 2010 only offers protection from discrimination on a certain limited number of grounds, Article 14's reference to 'other status' enables it to be relied upon to challenge differences in treatment between individuals who are similarly situated for a range of different reasons, although different types of discrimination attract different levels of scrutiny (including, following Hode \& Abdi v UK [2012], where the distinction is based on migration status). The prohibition of both direct and indirect discrimination on the grounds of sex is found in domestic and European human rights and equality law. ${ }^{3}$ It does not matter whether the difference in treatment complained of arises because the relevant duty-bearer (in this case, the State) has the express intention of disadvantaging a particular group, what matters is if this is the result (per DH and others v Czech Republic [2007]: paras 44, 169 which concerned 'unconscious racial bias').

Finally, under Article 14, indirect discrimination can be justified. The differential treatment of a protected group is not unlawful if the relevant distributive purpose is a legitimate one (pertains to a public or social 'good' for example) and there is a 'reasonable relationship of proportionality' between that purpose and the criteria adopted. Once differential treatment has been established, it is for the State to justify it ( $\mathrm{DH}$ and others $v$ 
Czech Republic [2007]: para 180). As Baroness Hale explained in Homerv Chief Constable of West Yorkshire Police [2012] at para 17:

The law of indirect discrimination is an attempt to level the playing field by subjecting to scrutiny requirements which look neutral on their face but in reality work to the comparative disadvantage of people with a particular protected characteristic.

In this article I subject to scrutiny the requirements of the immigration rules which distribute different migration statuses. This distribution will, accordingly, unlawfully indirectly discriminate against women if, without justification, it affects men and women differently to women's disadvantage. ${ }^{4}$

Drawing on the well-established principle (Essop [2017]; para 28) that indirect discrimination may be established on the basis of statistical information, this article draws on such data taken from over a ten-year period to show that British immigration law distributes certain migration opportunities differently to men and women. I then analyse the rules that create these migration statuses and examine the disadvantage they produce. The different statuses considered are compared with each other because statistically 'skilled labour migrant' operates as a proxy for 'male (skilled) migrant worker'; 'domestic worker' operates as a proxy for 'female (unskilled) migrant worker' whilst 'partner' operates as a proxy for 'wife'. Finally, I examine the relationship between the distributive purposes of the relevant rules and the criteria adopted to meet them. I consider and reject official justifications for disadvantageous facets of rules to demonstrate that they are not just productive of certain types of subjects and relationships, as Helena Wray and Elenore 
Kofman have persuasively argued (Wray, 2011; Kofman, 2012; Kofman, 2014a) but may also entail unlawful discrimination.

Two potential objections to these arguments can be anticipated and refuted. The first is that my comparison of partners and domestic workers with skilled labour migrants is invalid; that the rules that apply to domestic workers should, for example, be compared with the rules that apply to other 'low-skilled' labour migrants. Significantly, as will be seen, there is simply no 'low-skilled' employment category the majority of whose subjects are men. ${ }^{5}$ The refutation of this objection to my argument lies not in a search through all the possible migration statuses created by immigration law, however, but in a consideration of the premise on which the objection rests.

Every distribution of a social good, such as migration status, has a purpose and criteria that govern that distribution (Réaume, 2013; 10). The purpose of distributing labour migration statuses, for example, may be to benefit the national economy of the host state; the criteria that govern this distribution are the immigration rules which determine who may enter to work, under what conditions and for how long. An argument that seeks to reject potential comparators is one that is grounded in a prior claim as to the purpose and criteria adopted for the relevant distribution; it 'is by reference to this purpose that $\mathrm{X}$ is comparable to Y or not, as the case may be' (Réaume, 2013; 7). Comparison is required in discrimination law to show relative group disadvantage, but who a group may compare itself with can only be ascertained by reference to the purpose/criteria of the rule being impugned. It is only by bringing the purpose of the relevant distribution into view that we ascertain who a potential comparator may be. An argument that states that the rules that 
apply to domestic workers should be compared with those that apply to another unskilled labour migration category takes as its premise that the purpose of these rules is to distribute statuses according to 'skill' and that domestic workers are 'low-skilled'. If domestic work is thought to be simply incomparable with 'skilled' work then the Home Office's distributive purpose and criteria, the reasons it gives for distributing migration statuses to labour migrants and its assessment of the skill and value of different types of labour, are accepted without scrutiny. Determining the purposes of an immigration rule is not straightforward. Determining what a 'skill' is and who might have it is also not a question of fact, it is one of judgement. Later I demonstrate that if the Home Office's distributive criteria are subjected to scrutiny, it becomes apparent that the rules that apply to domestic workers and partners are grounded in stereotypical understandings of women's roles and attributes. Establishing that the immigration rules that apply to partners or domestic workers are based on stereotypes not only resolves any potential objections to the comparison of migration statuses engaged in in the sections that follow, but also goes to demonstrating that their disadvantageous treatment of women cannot be justified. As we shall see, 'justifications' based on such stereotypes do not have a legitimate aim and are unable, therefore, to operate as justifications as a matter of law.

The second potential objection to my arguments is that the discrimination law analysis undertaken should compare the number of applications from men and women for a particular migration status with the number of grants to men and women of it. An objector raising such an argument might contend that as more women than men apply to be spouses, there can be no discrimination if more women than men hold that migration status. Such objections miss the point of the analysis I engage in here. I am concerned with the creation 
and distribution of different migration statuses and the disadvantageous and potentially discriminatory consequences for migrant women (and men) of that creation and distribution. In conducting such an analysis, it is not relevant (in the first instance) that more women than men apply as partners, or that more men than women apply as skilled labour migrants (issues I do consider in section 4, where I evaluate potential justifications for the differential treatment of women and men and argue that the migration statuses considered are based on stereotypes). What is relevant is if the migration statuses the majority of whose subjects are women (partners/domestic workers) are, comparatively, more disadvantageous than the migration statuses the majority of whose holders are men (skilled labour migrants). These are the issues to which I now turn.

\section{CREATION OF A STATUS-BASED HIERARCHY}

In this section I set out the rules that apply to certain family and labour migrants, discussing the migration statuses they produce and their position within the status-based hierarchy established by British immigration law. The ever-shifting and highly complex nature of immigration law makes analysing migration routes or categories something akin to shooting at a moving target. The rules discussed here have, of necessity, been simplified and may have changed since the completion of this research (February 2019).

\section{Entering and remaining in the UK as a partner}

Partners (whether married/civilly-partnered or not), fiancé(e)s and proposed civil partners, children, parents, grandparents and other dependent relatives may all be given permission to join someone who is British or settled here via one of a variety of family migration routes, each of which requires particular criteria to be met before the relevant status is granted. The most statistically significant of these routes is that which enables someone to 
enter and remain in the UK with his or her British or resident spouse, civil-partner or unmarried partner (Home Office, 29 Nov 2018c).

To enter and remain as a partner, a number of conditions have to be met which relate to the applicant him or herself (aged 18 or over, able to speak English to a specified level), the couple's relationship (they have met, they are not related in certain ways, previous relationships have permanently broken down, the current relationship is genuine and subsisting) and how they will live in the UK (together, permanently) (Immigration Rules, Appendix FM: paras E-ECP.2.1-10, ELTRP 4.1). Applicants must also meet onerous financial requirements in the form of a minimum income threshold (currently $£ 18,600$ with an additional $£ 3,800$ for a first child and $£ 2,400$ for each child after that) but are limited in both the sources of income and forms of evidence they are able to rely on to do this (Immigration Rules, Appendix FM: E-LTRP.3.1). Once in the UK, the rules establish a five year 'route to settlement' whereby an applicant is granted an initial period of permission for thirty months (during which she may work but not access public funds) which may be renewed on application for another thirty months, after which she may apply for indefinite leave to remain (Immigration Rules, Appendix FM: D-LTRP, E-ILRP).

\section{Entering and remaining in the UK as a labour migrant}

Labour migration to the UK is, for the most part, organised through a five-tier points-based system (the PBS), in which permission to enter/remain is granted according to whether a labour migrant has certain skills or attributes. ${ }^{6}$ Entrepreneurs, investors and those considered to have 'exceptional talent' may receive a Tier 1 visa. Long-term 'skilled' employment is covered by Tier 2. Short-term employment by Tier 5 (Tier 3 of the PBS is currently suspended, Tier 4 covers students). The PBS operates hierarchically, creating a 
'labour-migration-status-based-hierarchy' within the general 'migration-status-basedhierarchy'. Those statuses which confer significant rights or benefits, such as the ability to bring family members or settle within a short(er) period, are at the 'top' of the PBS (Tier 1 and then 2) whilst those which confer the least, which require regular renewal for example, are at the 'bottom' (Tier 5). Permission to enter the UK as an overseas domestic worker (ODW), the labour migration route to which the fewest rights accrue, is given outside of the PBS.

More people enter the UK under Tier 2 of the PBS, which covers 'skilled', employer-sponsored workers, than they do in any other labour migration category. Tier 2 (General) Migrants must score 70 points (depending on the circumstances). Points are allocated on the basis of attributes which include speaking English to a particular level, having certain funds available, having a sponsor employer and a particular level of earnings. Permission is granted for periods up to five years (depending on the employment's duration) and may be renewed. After five years the applicant may apply for indefinite leave to remain (Immigration Rules, Part 6A Points-based system: 245H245HF). The family members of Tier 1 and 2 points-based system migrants may join them and can also work (but not access public funds).

In contrast, to be granted permission as an overseas domestic worker (ODW) in a private household, an applicant must have worked in their employer's home for at least a year and plan to travel to the UK with them. Applicants must work full-time as a domestic worker and plan to leave the UK at the end of six months (or at the same time as their employer, whichever is sooner. Domestic workers in diplomatic households can remain in the UK for longer periods of time). The employer and domestic worker must have agreed 
in writing the terms and conditions of the employment, conditions which include paying the minimum wage. Domestic workers cannot apply for settlement, their family members cannot apply to join them and they cannot seek to remain in the UK on a different basis. They cannot change employer or even change jobs for the same employer. They cannot access public funds (Immigration Rules Part 5: Working in the UK: 159A-C).

\section{THE DISTRIBUTION OF MIGRATION STATUSES}

\section{Family migrants: partners}

As others have observed (Charsley et al., 2012) it is disproportionately 'women-as-wives' who enter and then remain in the UK under the 'partner' route. In 2013, to take just one representative year in the period I review, $70 \%$ of those granted admission as a partner were 'wives', compared with $23 \%$ of men who were admitted as 'husbands.' 7 In each and every year over the fourteen year period considered, significantly more women than men, generally two thirds or more, entered and then remained in the UK as wives (Home Office, 29 Nov 2018a; Home Office, 29 Nov 2018c). I use the word 'wife' because, as noted above, this is the term that the Home Office uses in its statistical reports. That it does so (rather than referring to 'spouses' or 'women') is highlighted here to foreshadow the discussion of migration status and stereotypes I engage in later in this article.

\section{Labour migrants}

In contrast to family migration, it is not just that labour migration is predominantly male, but that men are more likely to be at the 'top' of the labour migration hierarchy as 'skilled migrants', whilst those present at the 'bottom end' of the labour migration spectrum, outside of the PBS as ODWs, are overwhelmingly women. 
In $200569 \%$ of those given permission to enter under Tier 2 and its pre-PBS equivalent were men. By 2014 this had risen to $75 \%$, the disproportion of men/women being given permission to enter on this basis appearing to remain broadly consistent throughout the period considered. ${ }^{8}$ Tier 2 is, therefore, particularly significant not just because it covers the majority of labour migrants, but because of the considerable disparity in the number of women and men granted permission to enter under it.

As we move 'down' the PBS (from a consideration of those the Home Office considers highly-skilled, through those who are skilled to those whose skills it values less, or indeed in the case of domestic workers, not at all) we see that $53 \%$ of those given permission to remain in the UK as temporary workers (Tier 5 migrants and its pre-PBS equivalent) were women in both 2005 and $2014 .{ }^{9}$ The proportion of women in a labour migration category is at its highest once we move out of the points-based system: $76 \%$ of those given permission to enter the UK as domestic workers were women in both 2005 and 2014. ${ }^{10}$ Tellingly then, the proportion of women and men in a particular employment category only equalises when we move down the PBS to consider temporary workers, and the proportion of women only exceeds that of men when we move out of the PBS entirely to consider the only remaining non-PBS employment category, that which applies to domestic workers.

\section{THE DISADVANTAGE PRODUCED BY DIFFERENT MIGRATION STATUSES: RIGHTS-RESTRICTION, DEPENDENCY AND PRECARITY}

Drawing on Bridget Anderson's (2010) influential analysis of migration law's 'fashioning' of precarious workers, the disadvantage that the rules summarised briefly above produces 
is explored here by reference to the reduction or restriction of migrants' rights, forced dependency and precarity. Of course, rights-reduction, dependency and precarity are not the only forms of disadvantage immigration law creates, nor are these forms of disadvantage distinct. The argument being made here is not that the migration routes, the majority of whose subjects are men, are unproblematic or do not also produce (sometimes significant) disadvantage. Labour migration routes into the UK have been restricted and subject to considerable change; there is an annual limit on the number of sponsorship certificates available under the Tier 2 , and prospective employers may also have to satisfy a resident labour market test (a test to see if the position could be filled by someone who is British/resident here). Rather, Anderson's insights into the way that immigration law creates classes of precarious and dependent employees have been developed and enhanced by a focus on gender and a consideration of family migration, to reveal how immigration law produces both the precarious workers and probationary wives of this article's title. Finally, many migrants who are partners or who undertake paid domestic work do not actually hold the relevant migration status of 'partner' or 'overseas domestic worker'. Such people may have permission to remain on another basis (as students or visitors for example) or have no permission to remain at all. A discussion of the disadvantage faced by these migrants is beyond the scope of this article.

\section{'Wives'}

Turning first to the partner route and its financial requirements, the rules which set out a 'minimum income threshold' which couples must meet for the migrant partner to be given permission to enter and remain. These rules are significant because not only must a couple demonstrate that they have substantial financial resources, but also where the applicant is 
to travel to the UK with or to join her partner, it is only income from his employment/selfemployment that is considered. ${ }^{11}$ Dependency for those seeking permission to enter as a partner is created by disregarding a woman's financial contributions, making her reliant on her husband's resources for the purposes of the immigration application. Preventing women from relying on earnings received outside of the UK, or anticipated UK earnings, (from secured employment for example) operates as a disincentive to those seeking permission in this category to seek employment before they enter, or to maintain it in their country of origin during the application process. Indeed, during this pre-entry period it makes more 'sense' under the rules for an applicant to support her husband to maximise his income, rather than to seek to secure her own. Once in the UK, the five-year 'probationary period' undermines women's autonomy, potentially affecting decisions about their family and professional lives (Charsley et al., 2016).

Different disadvantageous facets of the route may also interact with and reinforce each other. Precarity and dependency are created not just by the imposition of an immigration application mid-way through the five years, an application which is costly and in which the applicant must demonstrate that all the requirements of the rules continue to be met (if they are not, permission to remain is likely to be refused) but also by the application process itself. A wife must ask for her husband's signature on her immigration application. A husband's refusal to sign the form will result in the applicant becoming an 'overstayer', even if her marriage or relationship is continuing and all the requirements of the rules are satisfied (Home Office, 2016; section 15). A letter from a husband to the Home Office sent at any point during the five year period stating that the relationship has ended may result in his wife's permission to remain being curtailed, even if he does not tell her 
that he believes the relationship has ended (as occurred in Balakoohi [2012]). The dependency and accompanying precarity created by the 'probationary period' may also make a partner more vulnerable to experiencing domestic violence (OpCit Research London et al., 2013).

Finally, whilst the migration status given to partners does give them the right to work, the frequency with which permission must be renewed acts as a substantial barrier to actually securing employment (Kesete et al., 2015: 45). Settlement, or the promise of it, obscures the precarity of a route which tests the same requirements three times in five years and which enforces a woman's dependency on her British/resident partner throughout this period. Whilst the partner route confers benefits, the dependency and precarity created by the rules and processes discussed (briefly) here have significant consequences, in effect creating the migration status of 'probationary wife'.

\section{Domestic Workers}

There is a great disparity between the rules that apply to overseas domestic workers and those which apply to, for example, skilled labour migrants. A skilled or highly-skilled labour migrant may have the freedom to work or be self-employed, to change employers or employment type, to bring family members with them, extend their stay, stay in a different category or settle in the UK. Whilst dependency on an employer or 'designated competent body', and recent changes to limit skilled labour migration are certainly 
problematic, the disadvantage that accrues to the statuses given to skilled labour migrants is of a different order to that which accrues to domestic workers.

Those who hold the migration status of domestic worker are entirely dependent on their employer for that status, as is exemplified by the fact that, until as recently as 2016 , the visa stamped into a domestic worker's passport referred to her employer by name (personal correspondence between the author and NGO staff, available on request). Domestic workers who leave their employer lose their permission to remain in the UK, even if their employer has acted unlawfully or has been abusive (in some limited circumstances where a domestic worker has been trafficked, she may apply for permission to work for a different employer (Immigration Rules Part 5, Working in the UK: 159I$159 \mathrm{~K})$. Where trafficking is not the abuse complained of, or if a trafficking claim is not accepted by the relevant authorities and a domestic worker nevertheless 'chooses' to leave her employer but remain in the UK, her subsequent loss of migration status increases her likelihood of experiencing further exploitation (Mantouvalou, 2015).

The position of domestic workers in the UK is also precarious because they are permitted to work here for just six months. They are unable to extend this leave or vary it. They are never eligible for settlement in the UK. Finally, whilst rights do accrue, to differing extents, to almost all migration statuses, there are simply no rights, other than the right to work in their employer's household within the framework described, attached to the migration status of domestic worker.

As highlighted in relation to the partner route, different facets of a domestic worker's migration status may interact to amplify the disadvantage experienced. The 
isolation that results from being unable to bring family members, when combined with the requirement that they work only within their employer's household, serves to exacerbate domestic workers' dependency on their employers and therefore, the precarity of their position in the UK. The role that these rules play in increasing vulnerability to violence and facilitating exploitation have been highlighted by both the Supreme Court (Taiwo \& Anorv Olaigbe \& Ors [2016]) and empirical research (Mantouvalou, 2015).

\section{FROM DISADVANTAGE TO DISCRIMINATION}

The preceding discussion has demonstrated that immigration law produces a status-based hierarchy in which women are disproportionately the holders of those migration statuses which are precarious, which produce dependency and to which few rights accrue. Additional steps need to be taken, however, before it can be argued that these rules unlawfully discriminate against women. In this section I rely on Article 14 ECHR to evaluate the rules that determine who is accorded the migration status of partner or domestic worker, and some of their potential justifications, to argue that these rules may indirectly discriminate against women. Of course, the process of identifying, examining and rejecting potential justifications engaged in here is of a different order to that which would be carried out by a Court. It is sufficient, however, to require the Home Office to consider and remedy its treatment of migrant women, regardless of whether or not that treatment is subject to legal challenge (Fredman, 2014).

To recap: a distributive criterion will indirectly discriminate if, without justification, it affects men and women differently to women's disadvantage. Rules which impact on a woman's ability to work or change employers, which interfere with her ability to live in the UK and conduct an (equal) relationship with her partner all engage Article 8, 
the right to a private and family life. It is not necessary to show that the rules relating to partners or domestic workers themselves breach Article 8 (although they may), only that the 'facts at issue', the dependency, precarity and rights-restriction produced by the rules, 'fall within the ambit' of this right.

Under Article 14 ECHR, the State can justify aspects of the relevant immigration rules that disadvantage women. Whether or not a particular 'justification' can successfully ‘justify' differential treatment depends firstly on whether or not it reflects a legitimate aim. In the following paragraphs I start to evaluate as justifications the original legislative purposes of the particular immigration rules that have been shown to disadvantage women. Ascertaining the 'purposes' of immigration law is far from straightforward, however. Whilst recognising, therefore, that the rules I consider may have many 'purposes' (including those which are not explicitly stated) ${ }^{12}$ and that the Home Office is not bound to present or present only these purposes as justifications, I will accept at face value and analyse the Home Office's main stated explanations for the relevant rules. ${ }^{13}$ Home Office explanations which are grounded in stereotypes are identified and rejected.

When stereotypes are considered in discrimination law, it is usually in the context of a distributive criterion which is based on a stereotype that relates to a protected ground. For example, an employer seeking to employ an engineer who only wishes to hire men because he believes women are not good at maths will be directly discriminating against women by relying on stereotypical understandings of women's (and men's) attributes. I am not suggesting that the rules considered here are discriminatory because they specify that the applicant for a particular migration status be either male or female. Rather, I contend 
that the migration statuses of 'wife' and 'domestic worker' are premised on stereotypical understandings of men's and women's roles and attributes. Of course, 'traditional' employment practices such as the division between 'women's' and 'men's' jobs, or the expectation that a wife will bear the greater responsibility for caring for a home and family may explain why a greater proportion of women than men enter as domestic workers or partners (or it may not, Docquier et al., 2009; Kofman, 2012). The disadvantageous treatment of domestic workers on the grounds of sex cannot, however, be justified by reference to arguments which assert that women are more likely than men to be domestic workers or that such work is 'women's work' and therefore unskilled (Essop 2017: para 26). 'Justifications' based on such stereotypes do not have a legitimate aim and are unable to operate as justifications as a matter of law. As the Grand Chamber ruled in Konstantin Markin v Russia [2012] (which concerned men's access to parental leave):

The Court concludes from the above that the reference to the traditional distribution of gender roles in society cannot justify the exclusion of men, including servicemen, from the entitlement to parental leave. The Court agrees with the Chamber that gender stereotypes, such as the perception of women as primary child-carers and men as primary breadwinners, cannot, by themselves, be considered to amount to sufficient justification for a difference in treatment... (para 143)

In addition to having a legitimate aim, whether or not a particular 'justification' 'justifies' differential treatment also depends on whether there is a reasonable relationship of proportionality between the means employed and the aim to be realised. When assessing justification, the European Court of Human Rights employs a proportionality test which varies in intensity depending on the ground at issue, in conjunction with granting a 'margin of appreciation' to States (Arnardóttir, 2014). The UK's domestic courts engage in an analogous proportionality exercise in conjunction with showing deference to areas within 
the Government's 'discretionarily area of judgement' (Bamforth et al., 2008: 87). When assessing proportionality, the relevant Court must ascertain whether measures designed to meet the legitimate aim are rationally connected to it and are no more than is necessary to accomplish it (Bamforth et al., 2008: 81). Different parts of the UK's immigration rules have been subject to challenge both before the European Court of Human Rights and domestically on the grounds that they breach fundamental human rights and/or are discriminatory. Whilst 'very weighty reasons' are required to justify differential treatment on the grounds of sex, following Stec and others v UK [2006], this litigation has been concerned with (amongst other things), whether a justification offered in the immigration law context, and its relationship to the relevant legitimate aim, is 'not so manifestly unreasonable' as to exceed the wide margin of appreciation granted to Governments (Stec [2006]: paras 52 and 66)

\section{'Wives'}

Historically, women were prevented from retaining their property, nationality and bodily integrity following marriage, married women being considered in law as 'feme covert'. As Blackstone memorably explained:

By marriage, the husband and wife are one person in law: that is, the very being or legal existence of the woman is suspended during the marriage, or at least is incorporated and consolidated into that of the husband: under whose wing, protection, and cover, she performs everything. (1979: 430)

The laws that created couverture have now, of course, either been repealed or superseded. The Married Women's Property Act 1882 enabled some married women to own and control property independently of their husband. In 1948 women were able to retain their British nationality following marriage (rather than being automatically denaturalised, Irving, 2016). Marital rape finally became a criminal offence following $R \vee R$ [1991]. 
Notwithstanding these changes (and changes in social attitudes) the stereotype of the dependent wife persists, at least in part because of the legal rules and structures that continue to give it meaning. Such rules include the immigration rules discussed here which are both premised on, and reinforce, the stereotype (Anderson, 2013: chapter 3; Carver, 2016). Analogous arguments have also been made about US law (Calvo, 1991; Balgamwalla, 2014).

The Home Office states that the purpose of the rules that apply to partners is to ensure that those establishing their family life in the UK are 'genuine' families, able to 'integrate', who are not a burden on the 'taxpayer' (Home Office, July 2011; para 2.3). The financial rules (which disregard a migrant partner's financial contributions to the household during the pre-entry period) are justified by reference to the fact that applicants 'may' be financially dependent on their partner and that, therefore, they may seek support from 'the taxpayer' if their partner is unable/unwilling to continue to support them (Home Office, July 2011: 21-23). This justification is directly premised on the stereotype that wives are the financial dependents of their husbands, treating all migrant partners as if this were the case even when the Home Office's own research demonstrates that it is not (Home Office, July 2011: 21). The strength and salience of the 'dependent wife' stereotype is also evident in the fact that the Home Office consistently presents the 'migrant spouse or partner' as an altogether different person from 'the taxpayer', as if it were not possible for migrant wives to contribute to the economy, work and pay tax. Justifications premised on such stereotypes are unable, as a matter of law, to operate as such. It is also difficult to see any correlation between the purpose of the rules and these criteria. If financial dependency in some instances of marriage migration is a problem, then it is not one that can be resolved by 
treating all migrant partners as if they were so dependent. Furthermore, the financial requirements, combined with the condition that migrant partners have "no recourse to public funds' means that they are not a 'burden' to 'the taxpayer', and in any case, access to healthcare, for example, is permitted throughout the period the partner has permission to remain, as well as after settlement. The financial requirements are not, therefore, rationally connected to the legitimate aim they purport to pursue.

The Home Office argues that the five-year probationary period is necessary to test the genuineness of a relationship, to encourage 'integration' of the partner before settlement and to reduce the burden on the 'taxpayer' of the partner. The 'probationary period' is also directly traceable to the 'wife' stereotype. It treats and indeed makes migrant wives appendages of their 'sponsor' husbands for five years, not just in relation to their migration status (and all the rights that it bestows) but also during immigration processes, as demonstrated by the requirement that a husband signs his wife's application. The reasons given for these criteria also do not have a sufficiently proportionate relationship to the stated purposes of the rules. It is unclear, for example, how a relationship that lasts between two and five years (the difference between 'probationary periods' in the previous and current set of rules) can be said to be any less 'genuine' than one that lasts over five years. Whilst a probationary period of either one or two years might be considered to be a proportionate means of ensuring a relationship is genuine (genuine rather than say, enduring), one of five years (with an additional immigration application mid-way through) is arbitrary (drawing on Endicott, 2014) and wholly disproportionate because it is so much longer, for example, than the approach adopted in certain UK family law proceedings which may consider genuine a relationship that has lasted a few months. ${ }^{14}$ Similarly, 
stressing the need for wives to 'integrate' presupposes their separation (in the private sphere?) from wider society, a separation that is in fact facilitated and maintained by the dependency and precarity the rules create (Kesete et al., 2015).

\section{Domestic workers}

Women (and usually particular kinds of women) were and are believed to be naturally nurturing and therefore, particularly suited to caring for dependents and looking after the/a family home. Such work is, almost by definition, 'unskilled'. Feminist analyses of employment and the labour market have highlighted both the sexed/gendered stereotypes that underlie the categorisations of certain types of work and worker as either low/high skilled (Steinberg, 1990) and the idea that 'skill' itself can be determined objectively (McDowell, 2014). As Anne Phillips and Barbara Taylor argue '[s]kill definitions are saturated with sexual bias. The work of women is often deemed inferior simply because it is women who do it' (1980: 79).

A number of scholars have sought to explore and unpick this 'saturation' further. Jane Jenson (1989), for example, discusses skill differentiation (low/high) and attribution (women/men) by contrasting what are socially understood to be 'the talents of women' (including empathy, dealing with bodily fluids etc.) with the 'skills of men' (as demonstrable through the holding of certain qualifications). Eleonore Kofman's discussion of the unequal valorisation of certain types of knowledge/person similarly contrasts the classification of some kinds of knowledge as 'embrained' (that which is scientific, technical or 'objective' in some way) with that which is 'embodied' (uses the body to acquire learning and perform tasks, 'subjective') (2012: 583-4). Notwithstanding these critiques (and perhaps more importantly for this article's discrimination law argument) 
legislation and a raft of associated legal challenges, the woman-carer stereotype continues to impact upon almost every aspect of women's participation in the labour market, including the gender pay gap, the continued existence of sex segregated or gendered roles, the devaluation of caring work and the devaluation of all work (whether caring or not) that women do (Blau and Kahn, January 2016; Bovill, 2013; Bowlus and Grogan, 2009; Levanon et al., 2009; Muzio and Bolton, 2006).

According to the Home Office, the purposes of the labour migration rules are to encourage 'the brightest and the best, those who contribute to our economy and who are really needed by the UK', whilst ensuring that the majority of labour migrants return to their country of origin (Home Office, June 2011: 3). In comparison with those migrants who are 'really needed', domestic workers do not 'fill skills gaps' and 'those who enter in this capacity are not assessed against the economic needs of the country' (Home Office, June 2011: 3, 29-30).

It will be recalled that labour migration is primarily dealt with under the PBS, but that the domestic worker route has been maintained outside of this system. Putting to one side the considerable material disadvantage that pertains to this route, and imagining instead one that offered domestic workers the same rights and opportunities as those enjoyed by (other?) skilled migrants and it is evident that what is discriminatory about it is not 'just' the material disadvantage that accrues to its holders, but its treatment of domestic workers as if they and their skills are fundamentally different from all other types of worker and all other types of work. This is the case even though the PBS covers work as diverse 
as that done by investors, intra-company transferees, sports-persons, artists, healthcare professionals, charity and religious workers.

That a domestic worker can only work for one employer and for a limited period of time is justified by reference to both the unskilled nature of the work and the employer's ability to recruit workers from the UK 'labour pool' (Home Office, June 2011: 30-31). The 'tying' of domestic workers to their employers (both formally, by their migration status, but also tacitly, by naming an employer in the domestic worker's visa, as discussed above) has been justified in Parliament as follows:

Looking at our national interest, if wealthy investors, skilled workers and others with the potential to benefit our economy were unable to be accompanied by their domestic staff they might not come here at all but take their money and skills to other countries only too keen to welcome them (emphasis added. Hansard, 28 November 1990: column 1052).

If the ODW regime is a 'benefit' that accrues to someone other than the person whose rights are determined by it, its considerable disadvantages make 'sense'. The route changes demand structures in this part of the economy, depresses wages and prevents domestic workers from securing other, better employment, even if they have been exploited (it will be recalled that only domestic workers who have been trafficked may change employers). Whilst there is an extent to which this argument can also be applied to (again other?) 'skilled' labour migrants, the difference is that the relationship between them and their employers is one that is positioned as being mutually (although not necessarily 
symmetrically) beneficial. In contrast, the ability to bring 'their' domestic workers is a benefit that is bestowed upon the 'right' type of migrant, those with money for example.

Putting to one side the stereotypical characterisation of domestic workers as unskilled workers, justifications for disadvantage that treat those who experience it instrumentally (almost as chattels, per the above quote) either cannot be relied on as justifications for discriminatory treatment or, if they are, are wholly disproportionate. There is simply no reasonable relationship of proportionality between the aim (benefiting the employer) and the means used (disadvantaging 'their' domestic workers to such a considerable extent) given the myriad of alternatives the Government has at its disposal (tax breaks or less restrictive immigration rules for the employers themselves for example).

Of course the Home Office's justification for first, differentiating between domestic workers and all other workers and second, disadvantaging the former for the benefit of a particularly valued subset of the latter, is comprehensible only by reference to the sexed/gendered stereotypes discussed above. Such work and those who do it are deemed unskilled and un-valuable because it is impossible to separate the classification and valorisation of particular skills, talents or knowledge from the bodies of those who have them, whether 'naturally' or not (England and Folbre, 1999; Folbre, 2009; Jenson, 1989; Kofman, 2012). Justifications that rest on such stereotypes do not have a legitimate aim and cannot, therefore, operate as justifications for the differential and disadvantageous treatment of domestic workers as a matter of law.

Wives and domestic workers: differential or discriminatory treatment? 
Whilst the rules that apply to partners and domestic workers do not specify that the holders of such statuses must be women, they are predicated on stereotypical understandings of marriage, the role of men and women within it, women's work and women's skills. They are both, to coin a phrase, 'saturated with sexual bias' (Phillips and Taylor, 1980:79). Women who hold the status of partner or domestic worker are disadvantaged, therefore, not just by the material disadvantage that these statuses produce, but also by being treated as if the stereotype were true, as if they were dependent on their husbands or as if their work had no value. I contend that such treatment is a wrong in and of itself (see Moreau, 2004 for a discussion of this point). Men may also be disadvantaged by such stereotyping, their claims to family life interpreted as attempts to secure an immigration advantage, the value they accord to their familial relationships minimised and their contributions as carers dismissed (Griffiths, 31 October 2016; Wray, 2015). Whilst these stereotypes may be subject to challenge and have decreasing popular salience, their incorporation into the immigration rules accords them new significance. All women are harmed by this as the migration statuses strengthen the stereotypes, (re)making them anew. Whilst States may differentiate between and offer incentives to certain groups of migrants to attract them to their jurisdiction (Hode \& Abdi [2012]), justifications for disadvantaging migrant women that rest on such sexed/gendered stereotypes do not have a legitimate aim and cannot, therefore, operate as justifications as a matter of law (Konstantin Markin v Russia [2012]). Other explanations for particular facets of these two routes that create disadvantage have also been considered and rejected as disproportionate. Based on the statistical information presented and legal analysis conducted it can be concluded, therefore, that the rules that apply to wives and domestic workers indirectly discriminate against women. 


\section{IMMIGRATION LAW AND DISCRIMINATION AGAINST WOMEN}

Thus far I have focused on two migration statuses and their place within immigration law's highly complex and differentiated status-based hierarchy. If we take a step back, however, and consider migration for work, study, family and protection more broadly, we see that the family and labour migration routes analysed here are far from anomalous in their differential treatment of women and men. The majority of non-EU migrants come to the UK to study; this is followed by migration for work, family and protection (or 'other') reasons (Blinder, 28 June 2018). Men make up the majority of non-EU labour migrants whilst the majority of migrants whose basis for entry is a family relationship are women (Blinder, 14 June 2018; Blinder, 3 Jul 2018). Women also make up the majority of students (Blinder, 20 Jul 2017) whilst considerably more men than women apply for asylum (Blinder, 26 Oct 2017). That women are more likely to enter the UK as students (who cannot settle here and face considerable restrictions in their ability to work or take parental leave) or family migrants (whose migration statuses produce disadvantage which is either equivalent to or worse than that discussed in relation to the partner route) is significant. That most people who settle permanently in the UK do so on the basis of labour migration, a route the majority of whose subjects are men, is similarly noteworthy (Blinder, 20 July 2018).

An analysis of all the different immigration rules and the migration statuses that they produce is beyond the scope of this article. It is, however, possible to combine what we know about migration to the UK, the structure of immigration law and the particular rules examined in the preceding sections, to found a broader, normative claim about 
immigration law as a whole. Immigration law creates a status-based hierarchy. The disadvantageous position given to wives and domestic workers within this hierarchy is the product of indirect discrimination. It is not just wives and domestic workers that are disadvantaged by immigration law, however. (Female) students and other family migrants also appear to be situated disadvantageously whilst, at least according to one indicator (the ability to settle in the UK), (male) labour migrants appear to be more advantageously placed. Immigration law as a whole, therefore, disadvantages a significant proportion of the women whose migration status it determines, and this disadvantage is the product of discrimination which may be, at least in some cases, unlawful. Given the 'Europeanisation' of some aspects of family migration (Wray et al., 2014:211), increasing similarities in the way that certain States regulate labour migration (Boucher, 2016) and migration more broadly (Boucher and Gest, 2018; Dauvergne, 2016) this distribution pattern is likely to be repeated in other jurisdictions. Of course, not all migrant women are disadvantaged or discriminated against; some women do come to the UK as skilled labour migrants and obtain settlement within a (relatively) short period of time. However, many women are disadvantaged by immigration law and whether or not this disadvantage is (always/sometimes) the product of unlawful discrimination, its consequences are significant and enduring.

\section{CONCLUSION}

The Government does not have to provide a range of different migration routes to the UK nor give those migrants it does chose to admit the same or analogous rights to those enjoyed by British citizens/subjects. However, under the Equality Act 2010, the Home Office does have to have 'due regard' to the need to eliminate discrimination and to advance equality 
of opportunity. The migration statuses that it chooses to create, should not, as a matter of law if nothing else, unjustifiably disadvantage and discriminate against women. The Home Office should also eliminate treatment that is discriminatory, whether or not that treatment is challenged in the Courts. This requirement is all the more pressing when we consider the position not only of those women currently subject to British immigration law, but those who face being made subject to it and the proposed 'skills-based' immigration system following Brexit (HM Government, December 2018).

Contrary to these legal obligations, the immigration routes examined in this article may indirectly discriminate against women. Apparently neutral rules that apply to particular family and labour migrants in fact disadvantage women. Bridget Anderson's (2010) insights into immigration law's constitutive role in producing precarious workers illuminates the material disadvantage that results from this. Empirical evidence of women's experiences of the rules and doctrinal legal analysis reveal the 'fashioning' of migrant women as precarious workers and probationary wives. The disadvantage produced by immigration law's differential treatment of men and women is not limited to material disadvantage. An expressive harm accrues to all women by virtue of the existence of migration statuses that are premised on stereotypes. Justifications for the differential treatment of men and women, including those that are based on these stereotypes, are untenable.

Recognising that woman and men are disproportionately present in different migration categories, the constitutive role that immigration law plays in institutionalising precarity and dependency, and the disadvantage that results, enables us to identify ways in which immigration law may discriminate against women. This insight, when combined 
with a broader consideration of gendered patterns of migration to the UK and the statuses that such patterns produce, founds the normative claim that immigration law as whole disadvantages women.

\section{Notes}

1. Home Office statistical reports are updated quarterly and available here https://www.gov.uk/go vernment/collections/immigration-statistics-quarterly-release.

In relation to family migration, the reports distinguish between husbands, wives, civil partners, common-law spouses (there is no such thing in law) and same-sex partners (Home Office, 29 Nov 2018c). The immigration rules themselves refer to 'partners', a term which applies to those who are married, in a civil partnership or unmarried (whether in a same-sex or opposite-sex relationship).

2. The ECHR's prohibition of discrimination is the only one that is fully binding on the UK legislature. Where both the ECHR and Equality Act 2010 apply, the nondiscrimination analysis engaged in by the domestic courts subsumes the latter into the former as they are substantively similar.

3. Sex discrimination is prohibited by Equality Act 2010, Article $14 \mathrm{ECHR}$ and EU law, see for example Council Directive 76/207/EEC of 9 February 1976 on the Implementation of the Principle of Equal Treatment for Men and Women as Regards Access to Employment, Vocational Training and Promotion, and Working Conditions [1976].

4. Section 19 Equality Act 2010, Article 14 ECHR as applied in, DH and others $v$ Czech Republic [2007]. This case is presented as paradigmatic of the type of indirect discrimination law claim that this article relies on because the Grand Chamber drew on statistical information to establish relative group disadvantage, drawing support from definitions of indirect discrimination in EU law as well as from other international instruments.

5. The Seasonal Agricultural Workers' Scheme which ended in 2013 and concerned shortterm employment in the food industries might have been a potential comparator. It is similarly unclear who the comparator for a spouse might be.

6. The UK's Highly Skilled Migrant Program (HSMP) ran from 2002-8 when it was replaced by Tier 1 of the points-based system (PBS). The term 'highly-skilled migrant' and 'skilled migrant' are used to connote the position of migrants in Tiers 1 and 2 of the PBS respectively. 
7. The total number of people admitted as spouses or fiancé(e)s in 2013 was 15,800 of which 3,640 (23\%) were husbands, $11,100(70 \%)$ were wives, $360(2 \%)$ were men granted entry for marriage and $685(4 \%)$ were women granted entry for marriage, (Home Office, 29 Nov 2018a).

8. In 200566,214 migrants were given permission to enter the UK as Tier- 2 migrants and its pre-PBS equivalent of whom 45,475 (69\%) were men and 20,724 (31\%) were women. In 201452,501 migrants were given permission to enter the UK as Tier-2 migrants and its pre-PBS equivalent of whom 39,119 (75\%) were men and 13,355 (25\%) were women (Home Office, 29 Nov 2018b supplemented by data obtained by FOI request). See also Anderson (2013: Chapter 3) and Permits Foundation (2015).

9. In 200564,651 migrants were given permission to enter the UK as Tier-5 migrants and its pre-PBS equivalent of whom 30,395 (47\%) were men and 34,248 (53\%) were women. In 201442,197 migrants were given permission to enter the UK as Tier-5 migrants and its pre-PBS equivalent of whom 19,741 (47\%) were men and 22,441 (53\%) were women (Home Office, 29 Nov $2018 \mathrm{~b}$ supplemented by data obtained by FOI request).

10. In 200516,939 migrants were given permission to enter the UK as domestic workers of whom 4,005 (24\%) were men and 12,929 (76\%) were women. In 2014 16,753 migrants were given permission to enter the UK as domestic workers of whom 4,046 (24\%) were men and 12,707 (76\%) were women. (Home Office, 29 Nov 2018b supplemented by data obtained by FOI request).

11. Immigration Rules: Appendix FM and Immigration Rules Appendix FE-SE: Family members - specified evidence. Following $R$ (on the application of MM (Lebanon) [2017] these rules may be applied flexibly in certain very limited circumstances.

12. Czaika and de Haas note that policies selecting migrants by skill can be an 'indirect and covert measure' designed to influence the national and/or racial origins of prospective migrants (2013: 490). The absence of sex/gender from this argument is noticeable.

13. Consistent with the approach taken in the case law see, for example, $R$ (on the application of Quila and another) v SSHD [2011] The Government is, however, not confined to justifications presented in policy documents at the time that the relevant rules were adopted, British Airways v Starmer [2005].

14. Section 62(3) Family Law Act 1996 states that 'associated persons' (those who have genuine, family relationships) include those who 'have or have had an intimate personal relationship with each other which is or was of significant duration.'

\section{References}

Immigration Rules https://www.gov.uk/guidance/immigration-rules 
Anderson B (2010) Migration, Immigration Controls and the Fashioning of Precarious Workers. Work, Employment \& Society 24(2): 300.

Anderson B (2013) Us and Them?: The Dangerous Politics of Immigration Control: Oxford: OUP.

Arnardóttir OM (2014) The Differences that Make a Difference: Recent Developments on the Discrimination Grounds and the Margin of Appreciation under Article 14 of the European Convention on Human Rights. Human Rights Law Review 14.

Balgamwalla S (2014) Bride and Prejudice: How US Immigration Law Discriminates Against Spousal Visa Holders. Berkeley Journal of Gender, Law \& Justice 29.

Bamforth N, Malik M, O'Cinneide C, et al (2008) Discrimination Law: Theory and Context, Text and Materials, London: Sweet \& Maxwell.

Blackstone W (1979) Commentaries on the Laws of England (1765): University of Chicargo Press.

Blau FD and Kahn LM (January 2016) The Gender Wage Gap: Extent, Trends, and Explanations. IZA Discussion Paper No. 9656, Institute for the Study of Labor.

Blinder S (26 Oct 2017) Migration to the UK: Asylum. Migration Observatory briefing, COMPAS, University of Oxford.

Blinder S (20 Jul 2017) Non-European Student Migration to the UK. Migration Observatory briefing, COMPAS, University of Oxford.

Blinder S (14 June 2018) BRIEFING: Non-European Labour Migration to the UK. Migration Observatory briefing, COMPAS, University of Oxford.

Blinder S (20 July 2018) Settlement in the UK. Migration Observatory briefing, COMPAS, University of Oxford.

Blinder S (28 June 2018) Immigration by Category: Workers, Students, Family Members, Asylum Applicants. Migration Observatory briefing, COMPAS, University of Oxford.

Blinder S (3 Jul 2018) BRIEFING: Non-European Migration to the UK: Family Unification and Dependents. Migration Observatory briefing, COMPAS, University of Oxford.

Boucher A (2016) Gender, migration and the global race for talent, Manchester: Manchester University Press.

Boucher A and Gest J (2018) Crossroads: Comparative Immigration Regimes in a World of Demographic Change, Cambridge: Cambridge University Press.

Bovill D (2013) Patterns of Pay: Results from the Annual Survey of Hours and Earnings, 1997 to 2012. Office for National Statistics.

Bowlus AJ and Grogan L (2009) Gender Wage Differentials, Job Search, and Part-Time Employment in the UK. Oxford Economic Papers 61(2): 275-303.

Calvo JM (1991) Spouse-Based Immigration Laws: The Legacies OfCoverture. San Diego Law Review 28: 593.

Carver N (2016) 'For Her Protection and Benefit': The Regulation of Marriage-Related Migration to the UK. Ethnic and Racial Studies 39(15): 2758-2776.

Charsley K, Bolognani M, Spencer S, et al (2016) Marriage Migration and Integration Report. University of Bristol.

Charsley K, Storer-Church B, Benson M, et al (2012) Marriage-Related Migration to the UK International Migration Review 46(4): 861-890. 
Czaika M and De Haas H (2013) The Effectiveness of Immigration Policies. Population and Development Review 39(3): 487-508.

Dauvergne C (2009) Globalizing Fragmentation: New Pressures in Women Caught in the Immigration Law-Citizenship Law Dichotomy. In: Benhabib S and Resnick J (eds) Migrations and Mobilities: Citizenship, Borders and Gender. New York Univers ity Press.

Dauvergne C (2016) The new politics of immigration and the end of settler societies, Cambridge: Cambridge University Press.

de Hart B (2007) The Right to Domicile of Women with a Migrant Partner in European Immigration Law. In: van Walsum $\mathrm{S}$ and Spijkerboer $\mathrm{T}$ (eds) Women and Immigration Law: New Variations on Classical Feminist Themes. Routledge Cavendish.

Docquier F, Lowell BL and Marfouk A (2009) A Gendered Assessment of Highly Skilled Emigration. Population and Development Review 35(2): 297-321.

Endicott T (2014) Arbitrariness. The Canadian Journal of Law and Jurisprudence 27(1): 49.

England P and Folbre N. (1999) The Cost of Caring. The ANNALS of the American Academy of Political and Social Science 561(1): 39-51.

Folbre N (2009) Greed, Lust \& Gender: A History of Economic Ideas, Oxford, New York: OUP

Fredman S (2014) Addressing Disparate Impact: Indirect Discrimination and the Public Sector Equality Duty. Industrial Law Journal 43(3): 349-363.

Freedland M and Costello C (2014) Migrants at Work and the Division of Labour. In: Costello $\mathrm{C}$ and Freedland $\mathrm{M}$ (eds) Migrants at Work: Immigration and Vulnerability in Labour Law. OUP.

Government HM (December 2018) The UK's Future Skills-Based Immigration System (Cm 9722).

Griffiths M (31 October 2016) Invisible fathers of immigration detention in the UK. In Open Democracy. Availible at www.opendemocracy.net/5050/melaniegriffiths/invisible-fathers-of-immigration-detention (accessed 15 Feb 2019).

Home Office (29 Nov 2018a) Immigration Statistics: Entry Clearence Visa Tables. Available at: https:/www.gov.uk/government/publications/immigration-statisticsyear-ending-september-2018/why-do-people-come-to-the-uk-4-for-familyreasons.

Home Office (29 Nov 2018b) Immigration Statistics: Entry Clearence Visa Tables. Available at: https://www.gov.uk/government/publications/immigration-statisticsyear-ending-september-2018/why-do-people-come-to-the-uk-2-to-work.

Home Office $(29$ Nov 2018c) Settlement tables. Available at: https:/www.gov.uk/government/publications/immigration-statistics-year-endingseptember-2018/why-do-people-come-to-the-uk-4-for-family-reasons.

Home Office (2016) Application for an extension of stay in the UK as the partner of a person present and settled in the UK or as a partner of a person with refugee leave or humanitarian protection and for a biometric immigration document (Version 04/2016). Home Office.

Home Office (July 2011) Family Migration: A Consultation. 
Home Office (June 2011) Employment-related settlement, Tier 5 and Overseas Domestic Workers: A Consultation.

Irving H (2016) Citizenship, alienage, and the modern constitutional state: a gendered history, Cambridge: Cambridge University Press.

Jenson J (1989) The Talents of Women, the Skills of Men. In: Wood S (ed) The Transformation of Work,. Unwin and Hyman.

Kesete NZ, Thom D and Harvey H. (2015) Settling In. London: Eaves.

Kofman E (2012) Gendered Labour Migrations in Europe and Emblematic Migratory Figures. Journal of Ethnic and Migration Studies 39(4): 579.

Kofman E (2014a) Gendered migrations, social reproduction and the household in Europe. Dialectical Anthropology 38(1): 79-94.

Kofman E (2014b) Towards a Gendered Evaluation of (Highly) Skilled Immigration Policies in Europe. International Migration 52: 116.

Levanon A, England P and Allison P (2009) Occupational Feminization and Pay: Assessing Causal Dynamics Using 1950-2000 US Census Data. Social Forces 88: 865-891.

Macklin A (2003) Dancing across Borders: 'Exotic Dancers,' Trafficking, and Canadian Immigration Policy. International Migration Review 37(2): 464-500.

Mantouvalou V (2015) 'Am I Free Now?' Overseas Domestic Workers in Slavery. Journal of Law and Society 42(3): 329.

McDowell L (2014) Skills. In: Anderson B and Keith M (eds) Migration: A COMPAS Anthology. COMPAS.

Moreau S (2004) The Wrongs of Unequal Treatment. University of Toronto, Public Law Research Paper No. 04-04.

Muzio D and Bolton S (2006) Feminisation and Paradox: Stratification and Segmentation in Professional Contexts. Irish Journal of Management 27: 79-93.

O'Brien C (2016) Civis Capitalist Sum: Class as the new Guiding Principle of EU Free Movement Rights. Common Market Law Review 53: 937.

OpCit Research London, McCracken K, Cook K, et al (2013) Access to Shelters of Undocumented Migrant Women Fleeing Domestic Violence: The Legal and Practical Situation in the Member States. Directorate General for Internal Policies, Policy Department C: Citizens' Rights and Constitutional Affairs.

Permits Foundation (2015) The Impact of Removing the Unrestricted Right of

Dependants to Work in the UK. Available at https://www.permitsfoundation.com/wpcontent/uploads/Permits-Foundation-submission-to-the-MAC-on-Tier-2-dependants.pdf (accessed 2 Feb 2019)

Phillips A and Taylor B (1980) Sex and Skill: Notes towards a Feminist Economics. Feminist Review 6: 79-88.

Réaume D (2013) Dignity, Equality, and Comparison. In: Hellman D and Reibetanz Moreau S (eds) Philosophical Foundations of Discrimination Law. Oxford: OUP.

Reay L (28 November 1990) 523 HL Debs., column 1052. Hansard.

Shutes I and Walker S (2018) Gender and Free movement: EU migrant women's Access to Residence and Social Rights in the UK. Journal of Ethnic and Migration Studies 44(1): 137-153.

Steinberg RJ (1990) Social Construction of Skill: Gender, Power, and Comparable Worth. Work and Occupations 17(4): 449-482. 
van Walsum S (2006) Transnational Mothering, National Immigration Policy and the European Court of Human Rights. In: Shah P and Menski W (eds) Migration, Diasporas and Legal Systems in Europe. Routledge Cavendish.

Wray H (24 April 2015) Spousal Migration, Gender and UK Immigration Law. In Border Criminologies. Availible at www.law.ox.ac.uk/research-subject-groups/centrecriminology/centreborder-criminologies/blog/2015/04/spousal-migration (accessed 15 Feb 2019).

Wray H (2006) An Ideal Husband? Marriages of Convenience, Moral Gate-keeping and Immigration to the UK. European Journal of Migration and Law 8: 303-320.

Wray H (2011) Regulating Marriage Migration into the UK, Farnham: Ashgate.

Wray H (2015) "A Thing Apart": Controlling Male Family Migration to the United Kingdom. Men and Masculinities 18(4): 424-447.

Wray H, Agoston A and Hutton J (2014) A Family Resemblance? The Regulation of Marriage Migration in Europe. European Journal of Migration and Law 16(2): 209-247.

Wray H and Kofman E (18 February 2016) The Financial Requirements to Sponsor an Overseas Spouse. In Middlesex Minds. Availible at https://mdxminds.com/2016/02/18/the-financial-requirements-to-sponsor-anoverseas-spouse/ (accessed 15 Feb 2019).

Yuval-Davis N, Wemyss G and Cassidy K (2018) Everyday Bordering, Belonging and the Reorientation of British Immigration Legislation. Sociology 52(2): 228-244.

\section{Cases cited}

\section{United Kingdom}

R v R [1991] UKHL 12

British Airways v Starmer [2005] IRLR 862

$\mathrm{R}$ (on the application of Quila and another) v Secretary of State for the Home Department [2011] UKSC 45

Balakoohi [2012] EWHC 1439 (Admin)

Homer v Chief Constable of West Yorkshire Police [2012] UKSC 15

Taiwo \& Anor v Olaigbe \& Ors [2016] UKSC 31

Essop and others v Home Office [2017] UKSC 27

$\mathrm{R}$ (on the application of MM (Lebanon) and others) v Secretary of State for the Home Department [2017] UKSC 10

\section{European Court of Human Rights}

East African Asians v UK [1973] 3 EHRR 76

Abdulaziz, Cabales and Balkandali v UK App nos 9214/80; 9473/81; 9474/81 (ECtHR, 28 May 1985)

Stec and others v UK App nos 65731/01 and 65900/01 (ECtHR, 12 April 2006)

DH and others v Czech Republic App no 57325/00 (ECtHR, GC 13 November 2007)

Weller v Hungary App no 44399/05 (ECtHR, 31 March 2009) 
Konstantin Markin v Russia App no 30078/06 (ECtHR, GC, 22 March 2012)

Hode \& Abdi v UK App no 22341/09 (ECtHR, 6 November 2012)

Emel Boyraz v Turkey Application no 61960/08 (ECtHR, 2 Dec 2014)

Biao v Denmark App no 38590/10 (ECtHR GC, 24 May 2016) 